\title{
BMJ Global Health Reconceptualising health security in post-COVID-19 world
}

\author{
Sadia Mariam Malik (D) , Amy Barlow, ${ }^{2}$ Benjamin Johnson ${ }^{2}$
}

To cite: Malik SM, Barlow A, Johnson B. Reconceptualising health security in post-COVID-19 world. BMJ Global Health 2021;6:e006520. doi:10.1136/ bmjgh-2021-006520

Handling editor Seye Abimbola

Received 4 June 2021

Accepted 6 July 2021

Check for updates

(c) Author(s) (or their employer(s)) 2021. Re-use permitted under CC BY-NC. No commercial re-use. See rights and permissions. Published by BMJ.

${ }^{1}$ Economics, York University, Toronto, Ontario, Canada ${ }^{2}$ Political Science, York University, Toronto, Ontario, Canada

Correspondence to Dr Sadia Mariam Malik; smmalik@yorku.ca

\section{ABSTRACT}

While drawing upon the existing literature and policy documents on health security and its practice at the national and global levels, this article shows that the idea of health security has mostly remained rhetoric or at the most conceptualised and operationalised within the narrow Westphalian tradition of protecting nation states from external threats. By undertaking a critical examination of the national security strategies of some powerful G-20 countries, we show that non-traditional threats such as infectious diseases and pandemics are either absent from the list of potential threats or are accorded a weak priority and addressed within the state and military-centric notion of security. This approach has shortcomings that are laid bare by the ongoing pandemic. In this article, we show how national and global health security agendas can be advanced much more productively by mobilising a wider securitisation discourse that is driven by the human security paradigm as advanced by the United Nations in 1994, that considers people rather than states as the primary referent of security and that emphasises collective action rather than competition to address the transnational nature of security threats. We discuss the relevance of this paradigm in broadening the concept of health security in view of the contemporary and future threats to public health.

\section{INTRODUCTION}

Despite the widespread usage and acceptance of the significance of 'health security' in academic and policy discourses, there is little consensus on what this term actually means. ${ }^{12}$ This is primarily due to the interdisciplinary disposition of the term-since health and security correspond to different disciplines-and to its usage in a variety of contexts (individual, national and global) for a variety of purposes. At the individual level, for instance, health security refers to all aspects of public health that protect the vital core of human lives. ${ }^{3}$ At the national and global level, the term 'health security' usually refers to protecting people from those public health threats-such as infectious diseases and bioterrorism-that pose threats to national and international peace and stability. Since the term 'security' invokes concerns of urgency, power and the

\section{Summary box}

The notion of health security both at the national and global level has mostly been defined and operationalised within the narrow concept of security that is grounded in Westphalian tradition of protecting states from external public health threats through a limited set of emergency measures.

- The current pandemic has exposed the shortcomings of the existing approach to securitise health in both the developing and the developed world.

- We propose a reconceptualisation of the notion of health security by adopting a wider, ethical, and a more holistic notion of security that is adequately equipped to deal with the contemporary and future public health threats in an effective manner.

- The concept of human security, as conceived and advanced by the United Nations in 1994, has some distinctive features that can serve as a useful guide in reconceptualising the notion of health security in a more inclusive, integrated and holistic manner.

legitimate use of extraordinary means, it is often deployed strategically to position public health on the global agenda, seek political attention and secure financial resources. ${ }^{4-6}$

In general, the term health security refers to the policy areas in which health and security overlap. ${ }^{7}$ Different conceptions of 'health' and 'security' therefore produce different concepts of health security. In a macrosetting, 'health' is mainly used in a public health context referring to the collective actions of the society to protect population health. The term 'security' is defined by scholars of International Relations (IR) as protection from threats that pose risks to the survival and existence of a designated referent object (traditionally the state and its sovereignty) and that justify extraordinary mobilisation of the state and emergency measures. ${ }^{8}$

Three questions of central importance emerge when it comes to defining the notion of security: security for whom, security against what and security by what means? In the traditional military-political understanding of security, it is the state that is protected against external threats through military means. This 
notion of security is grounded in the Westphalian notion of sovereignty and political realism that are based on the idea that in an anarchical international system-where there is no governing authority above the states-the principal actors in the international arena are the states that act in their own self-interest to protect their sovereignty. This theoretical perspective is the most influential and parsimonious theoretical frames to date among North American scholars who had and continue to have enormous influence on political leadership in the West. It continues to dominate our understanding of global politics, the interactions between states, and the national security strategies of states. Scholars have questioned this mode of theorisation on several grounds, chief among them include its overemphasis on state as the central locus of analysis, its removal of people from the equation, its overemphasis on military threats and territorial security, its disregard to the damage done to states who are not part of the West, its abstraction from the fact that states do actually cooperate with each other to achieve mutual goals, its inadequacy in explaining security in an interdependent and globalised world, and its reinforcement of imperialism and highly militaristic national security strategies. ${ }^{7-11}$ Despite these drawbacks, realism and neorealism retain their influence and in doing so reinforce a narrow conception of national security that is no longer indicative of the contemporary nature of threats particularly after the Cold War.

In response to the perceived shortcomings of the narrowly defined state and military-centric notion of security, European IR scholars developed Critical Security Studies (CSS) as a way to widen and deepen the security discourse by incorporating both traditional and non-traditional security threats (such as those related to the economy, public health, food security, race, gender and the environment) and by including people as the referent object of security. An important offshoot of the CSS is the Copenhagen School of Security Studies that was launched in $1983 .{ }^{8}$ This approach adopted a social constructivist approach to explain the securitisation of an issue as a socially and politically constructed process involving a speech act conducted by a securitising actor who makes a 'securitising move' by presenting an issue as an 'existential threat'. Whether the issue becomes securitised depends on the logic presented and whether the audience accepts it. ${ }^{8}$

Despite the evolution in the theoretical perspectives to conceptualise security, we argue that the practice of security in national and global governance frameworks is largely dominated by the state and military-centric notion of security. This concept of security, when deployed to securitise health, is exclusively focused on exogenously originating infectious diseases and bioterrorism, and suggests improved intelligence of the outbreak, border security, and public health emergency response measures to counter them. While this appears to be a highly focused and parsimonious strategy to protect states from external public health threats in the short run, its effectiveness in improving health systems and health outcomes that can mitigate the chances of occurrence of acute public health events and their effects on the ordinary population is questionable, especially in the long run.

In this article, we discuss and evaluate the existing concept and practice of health security and propose its reconceptualisation in accordance with the human security paradigm presented by the United Nations (UN) in 1994. We discuss certain distinctive features of this paradigm and highlight its relevance and effectiveness in securitising public health especially in view of the contemporary and future public health threats.

\section{HEALTH SECURITY AT THE NATIONAL LEVEL}

At the national level, our analysis indicates that the concept of health security is operationalised within the traditional state and military-centric notion of national security emphasising protection against those public health threats that pose a threat to the peace, sovereignty and economic interests of the state. Bioterrorism, infectious diseases and pandemics are the potential security threats because they can potentially lead to (1) erosion of public trust in state institutions potentially leading to the failure of the social contract between the citizens and the state; (2) economic instability leading to weak state capacity and heightened risks of war in vulnerable regions; (3) heightened incentives for some actors to exploit the situation and create turmoil; (4) risk of mass migration of people escaping the fragile states and posing border security challenges to other countries; and (5) increased risk of infection by military personnel deployed in foreign countries. ${ }^{12} 13$

Although epidemics have historically been seen as threats to the peace and stability of states in general and the economic interests of the elite groups in particular, infectious diseases and bioterrorism were rarely on the list of national security threats prior to 1990 . It was only in mid-1990s when increased global connectivity, brought about by globalisation, heightened the risk of cross-border transmission of infectious diseases that these threats started appearing in the lists of national security threats in some countries. The anthrax attack in 2001 in the USA and the cross-border spread of infectious diseases such as AIDS, SARS and Ebola prompted countries such as the USA, France, Germany and UK to include protection against them in their national security agendas. In 2001, the Clinton Administration declared HIV/AIDS as national security threat and in 2002, the US Global Pathogen Surveillance Act was passed that acknowledged infectious diseases as security threats.

Despite this recognition, the current national security strategies of most countries, including the most powerful G-20 countries, either fail to acknowledge pandemics and infectious diseases as potential security threats or accord a weak priority often treating them as 'threat amplifiers' potentially undermining the security of military personnel (refer to table 1). An examination of the national security 


\begin{tabular}{|c|c|c|c|}
\hline Country & $\begin{array}{l}\text { Policy document } \\
\text { reviewed }\end{array}$ & Major emphasis & $\begin{array}{l}\text { Health security threats identified? Yes/ } \\
\text { no }\end{array}$ \\
\hline USA & $\begin{array}{l}\text { National Security } \\
\text { Strategy }(2017)^{40}\end{array}$ & $\begin{array}{l}\text { 'Principled realism that is guided by outcomes not } \\
\text { ideology' with 'interstate strategic competition' as } \\
\text { the 'primary concern in national security'. }\end{array}$ & $\begin{array}{l}\text { Yes, biothreats (such as anthrax) and } \\
\text { pandemics (such as Ebola and SARS)- } \\
\text { but accorded weak priority }\end{array}$ \\
\hline India & $\begin{array}{l}\text { Ministry of Defense- } \\
\text { Annual Report } \\
(2019)^{41}\end{array}$ & Geostrategic concerns and military forces. & No \\
\hline China & $\begin{array}{l}\text { Defence } \\
\text { White Paper } \\
(2019)^{42}\end{array}$ & $\begin{array}{l}\text { Rapid economic growth; technological } \\
\text { advancements with respect to weapons systems; } \\
\text { and the shifting international geostrategic landscape, } \\
\text { particularly in relation to the USA. }\end{array}$ & No \\
\hline Japan & $\begin{array}{l}\text { Security and defence } \\
\text { policy }(2020)^{18}\end{array}$ & Regional security and geostrategic concerns. & $\begin{array}{l}\text { No, but COVID-19's effects on military } \\
\text { operations and strategic competition are } \\
\text { emphasised }\end{array}$ \\
\hline Russia & $\begin{array}{l}\text { National Security } \\
\text { Strategy }(2017)^{43}\end{array}$ & $\begin{array}{l}\text { The security policy is officially 'multidimensional.' } \\
\text { However, in practice it is overwhelmingly focused on } \\
\text { the military and 'hard power tools'. }\end{array}$ & $\begin{array}{l}\text { Yes, explicit connection between } \\
\text { pandemics, health and national security }\end{array}$ \\
\hline South Africa & DOD report $(2019)^{44}$ & $\begin{array}{l}\text { State sovereignty; territorial integrity; national and } \\
\text { economic development; and regional stability in the } \\
\text { African continent. }\end{array}$ & Yes, infectious diseases \\
\hline Indonesia & $\begin{array}{l}\text { Defence White Paper } \\
(2015)^{45}\end{array}$ & $\begin{array}{l}\text { Military-centric with a focus on internal control and } \\
\text { consolidation of the nation state. }\end{array}$ & Yes, infectious diseases \\
\hline Canada & $\begin{array}{l}\text { National Security } \\
\text { Policy }(2020)^{46}\end{array}$ & $\begin{array}{l}\text { Protection of Canadians at home and abroad; } \\
\text { international security and protection of allies. } \\
\text { Emphasizes protection from terrorism and cyber } \\
\text { security threats. }\end{array}$ & $\begin{array}{l}\text { Yes, mentions the globalised threat of } \\
\text { infectious disease but no action plan. The } \\
\text { most recent defence strategy of Canada } \\
\text { does not mention pandemics or other } \\
\text { non-traditional threats. }{ }^{47}\end{array}$ \\
\hline Australia & $\begin{array}{l}\text { Strong and Secure: } \\
\text { A Strategy for } \\
\text { Australia's National } \\
\text { Security }(2013)^{48}\end{array}$ & $\begin{array}{l}\text { Countering terrorism, espionage and foreign } \\
\text { interference; preserving Australia's border integrity; } \\
\text { and promoting a secure international environment } \\
\text { conducive to advancing Australia's interest. }\end{array}$ & Yes, pandemics and biothreats \\
\hline UK & $\begin{array}{l}\text { National Security } \\
\text { Capability Review } \\
(2018)^{49}\end{array}$ & $\begin{array}{l}\text { Strengthening defence and armed forces; countering } \\
\text { terrorism; cyber security and fighting organised } \\
\text { crime. Upholding rules-based international order is } \\
\text { also emphasised. }\end{array}$ & $\begin{array}{l}\text { Yes, diseases and natural hazards. } \\
\text { However, in a recent 'Integrated Review' } \\
\text { of UK's foreign policy, defence, security } \\
\text { and International Development, global } \\
\text { health security remains absent. }\end{array}$ \\
\hline France & $\begin{array}{l}\text { White Paper Defence } \\
\text { and National } \\
\text { Security }(2013)^{51}\end{array}$ & $\begin{array}{l}\text { Protecting the sovereignty of the country with key } \\
\text { priority areas as protection from terrorism, organised } \\
\text { crime and cyberattack while securing critical } \\
\text { infrastructure with an overarching focus on military } \\
\text { and defence industry. }\end{array}$ & $\begin{array}{l}\text { Yes; pandemics, WMD and natural } \\
\text { disasters }\end{array}$ \\
\hline Italy & White Paper $(2020)^{52}$ & $\begin{array}{l}\text { Defence of the state, the Euro-Atlantic and Euro- } \\
\text { Mediterranean area, and the development of peace } \\
\text { and international security. }\end{array}$ & No \\
\hline $\begin{array}{l}\text { European } \\
\text { Union }\end{array}$ & $\begin{array}{l}\text { European Security } \\
\text { Strategy }(2009)^{53}\end{array}$ & $\begin{array}{l}\text { Weapons of mass destruction (WMD), terrorism, } \\
\text { cyber security, energy security, climate change. }\end{array}$ & No \\
\hline
\end{tabular}

DOD, Department of Defense.

strategies also shows an apparent lack of strategic interaction between the national security apparatus and the health and emergency response departments. Many countries like the USA and UK have national biodefense strategies as well as national health security strategies but these have practically remained unintegrated and independent from their national security strategies particularly before the ongoing pandemic. Likewise, investment in domestic health infrastructure-that is critical to respond effectively to public health emergencies-remains divorced from the national security strategies and apparatuses. This disconnect appears futile given that many countries recently adopted a 'whole-ofgovernment' approach by deploying military personnel while responding to COVID-19. China's response to the COVID-19 pandemic, for instance, is widely characterised as being analogous to a wartime effort through its 'wholeof-government' approach to combat the virus. ${ }^{14-17}$ In 
Japan, the Self Defense Forces have played a supporting role in terms of material and logistical support for COVID-19 related efforts by implementing 'disaster relief' operations as Japanese citizens returned to Japan during the initial spread of the virus. ${ }^{18}$ In India, military forces were mobilised under 'Operation Namaste' to respond to COVID-19 by providing material, logistical, and technical support for quarantine and containment measures. ${ }^{19}{ }^{20}$ In South Africa and Indonesia too, the military provided the material and logistical support.

The active involvement of military that mimics a classic war-like effort in providing logistical support might have been an effective emergency response strategy to contain the COVID-19 pandemic in these countries, yet this approach is likely to be counterproductive from a global perspective as it is inherently nationalist and can potentially undermine the collaborative effort needed to promote global public health.

\section{HEALTH SECURITY AT THE GLOBAL LEVEL}

At the global level, the state-centric notion of security guided by political realism retains its influence. ${ }^{26}{ }^{21}$ For instance, the Global Health Security Initiative (GHSI) that consists of an informal network of countries and organisations (Delegations of the GHSI include Canada, France, Germany, Italy, Japan, Mexico, the UK, the USA, and the European Commission. The WHO serves as an observer.) that came together shortly after the September 2011 terrorist attacks-focuses its effort on fighting and preventing the risk of bioterrorism as a way to improve global health (http://ghsi.ca/about/). Likewise the Global Health Security Index, prepared by the Johns Hopkins Centre for Health Security to assess health security-related capabilities across 195 countries, is primarily focused on preventing, detecting and responding to infectious disease outbreaks (https:// www.ghsindex.org/about/).

This approach is criticised on several grounds. First, there is a great deal of politicisation in terms of who sets the security agenda, who is being protected and what is it that we need protection from. Clearly, by privileging one set of concerns-such as infectious diseases and outbreak containment-more than others, the interests of highincome countries are argued to be high on the agenda considerations. ${ }^{222}$ Analysts also argue that the protection of these interests by powerful countries is also reflected in the actions taken by some multilateral institutions such as the WHO that are mandated with the promotion of global health security. ${ }^{7}$ Second, it is argued that the state-centric notion of security guided by political realism may result in health security dilemma since it is based on competitive logic that may hinder cooperation that is central to achieving global health security. ${ }^{23} 24$

Finally, the approach is criticised on the basis of its narrow focus on acute public health events such as infectious diseases, and containment strategies aimed at improved surveillance, outbreak alert systems, border security and emergency preparedness. ${ }^{6}$ Ultimately, pandemics are public health issues and fighting against them effectively involves the adoption of a holistic and multisectoral approach that emphasises prevention through primary hygiene and sanitation, a universal basic healthcare coverage, poverty reduction and tackling social exclusion. It also involves removing sanctions against vulnerable states, ending military conflicts across the world, addressing the structural sources of global inequity, and promoting global solidarity and collaboration.

In what follows, we provide a number of arguments to show how the above-mentioned limitations of securitising health within the narrow state-centric notion of security can be countered through the adoption of a broader securitisation approach driven by the human security paradigm.

\section{RECONCEPTUALISING HEALTH SECURITY USING THE HUMAN SECURITY PARADIGM}

Although the intellectual roots of the concept of human security can be traced as far back as 1940s in the speeches of American President Franklin D Roosevelt where he referred to 'freedom from fear' and 'freedom from want' as essential freedoms that people everywhere in the world must have, the concept was formally launched by the UN in 1994 in its annual Human Development Report. This was the time when the world was witnessing two major transformations: (1) the end of Cold War, that had brought about a major shift in the nature of security threats from interstate to intrastate conflicts ${ }^{25}$ and (2) the onset of globalisation that had increased the vulnerability of the Global South to downside risks. ${ }^{26}$ By defining human security as 'protection from such chronic threats as hunger, disease and repression', as well as 'protection from sudden and hurtful disruptions in the pattern of daily life,' the concept of human security was linked to both human development and human rights ${ }^{27}$ while maintaining its distinction by emphasising downside risks, focusing on sudden change rather than the level of human well-being, and emphasising the significance of early warning and prevention. ${ }^{28}$ It is a broad, multidimensional and people-centred paradigm of security that does not aim to replace the traditional concept of security but simply widens it by including traditional as well as non-traditional threats. It emphasises seven dimensions of security that people need in order to lead dignified and fulfilling lives. Health security is one of those dimensions. Other dimensions include food, economic, environmental, personal, political and community security. In contrast to the exclusive focus on infectious diseases by the traditionally practised concept of health security, the human security-driven concept of health security includes a broad range of threats to health security including communicable and non-communicable diseases, and emphasizes holistic and multisectoral solutions that include strengthening health systems, 
providing universal health coverage, and eradicating poverty and social exclusion.

The concept of human security can best be situated within the CSS since it widens the security agenda by including traditional and non-traditional threats and deepens it by considering people rather than the state as the primary referent of security. ${ }^{27}$ Underpinned by Sen's people-centred development paradigm based on his Human Development and Capability Approach, ${ }^{3}{ }^{29}$ the concept of human security was launched and operationalised in the UN system by Mahbub ul Haq, the author of the 1994 Human Development Report and the chief architect of the UN Human Development Index. By shifting the focus away from territorial security of the state to the security of individual human beings, Haq foresaw that the battle of human survival in future will be fought not by defending national borders but by promoting a collective realisation of the interconnectedness of the fate of human race and by evoking the compassion that makes us humans and joins us as humanity. In contrast to the concept of territorial security that divides nations, human security joins them. ${ }^{30}$

The concept of human security, as conceived by Haq and launched by the UN, was quite anti-colonialist in its outlook as evident, for instance, from its emphasis on development cooperation on an equal footing; its appeal to the rich nations to close their military bases; its condemnation of the commercial motives of military assistance to the developing countries; its emphasis on the need to regulate international trade in arms by curbing the transfer of weapons to potential trouble spots; its calls to the poor nations to divert huge military spending toward human development; and its emphasis on the need for a new framework of global governance and institutions, based on a social contract at the global level parallel to the social contract that states have with its citizens, to respond to global challenges of human security. ${ }^{27}$

Notwithstanding its broad dimensions and its anticolonialist outlook, the concept of human security was pursued narrowly and operationalised selectively within the political and economic order that maintained the status quo. Analysts argue that the concept has been co-opted by some states to promote their political and foreign policy agendas, and has often been used as a justification for interventionist foreign policy like peace keeping missions. ${ }^{31}$ Critics also argue that Japan, Canada and Norway adopted human security only as their foreign policy tools and not as a tool to address the domestic insecurities of certain groups of their local population. ${ }^{31} 3233$

While some analysts blame the conceptual depth and breadth of the concept as being responsible for the vagueness and its narrow uptake as a concept, ${ }^{34}{ }^{35}$ the supporters of the concept view the conceptual breadth as the strength since it gives the concept the dynamism and the subjectivity that it needs. ${ }^{32}$ It allows the concept many variants to reflect different priorities in different times and places. ${ }^{36}$ It provides space for contextualisation and local interpretation and ranking of threats. It is well attuned to the changing vulnerabilities of humankind and is malleable to reflect new threats to security. While we agree that the concept of human security has been co-opted by states and is not practised in its true holistic formulation, we contend that the original concept of human security, as advanced by the UN in 1994, has some distinctive features that can guide us in broadening the notion of health security.

First, the concept is centred on people as the primary objective of security while recognising that the security of states is inevitably tied to the security of its people. Evidence has shown that human insecurity and social injustice are often the root causes of the failure of social contract between the citizens and the state and have led to violent conflict and disintegration of states in many instances (A major factor (among others) in the partition of India in 1947 has been the role of social exclusion of Muslims in undivided India. Later the social, political and economic exclusion of Bengalis in East Pakistan led to the disintegration of Pakistan in 1971; https://www. nytimes.com/2020/09/22/opinion/trump-nationalsecurity.html?action $=$ click\&module $=$ Opinion\&pgtype $=$ Homepage (accessed on 22 September 2020)).

Second, the concept of human security is based on a multisectoral approach that recognises that threats to security are interconnected across various sectors and across various levels (individual, national, international and global), suggesting that security agenda cannot be pursued effectively in a compartmentalised approach. Health insecurity, for instance, may lead to economic insecurity and economic insecurity may lead to food insecurity. Likewise, the concept emphasises the geographical and spatial connectivity of threats, a feature also referred to as the 'indivisibility' of threats that implies that transnational threats such as infectious diseases cannot be addressed in silo, leading us to the concept's third important feature: its emphasis on collective action and interstate cooperation to address challenges of global dimension. The concept recognises the sovereignty of states, but at the same time is sceptical of the capacity of states to provide global human security while calling for non-state actors and transnational civil society movements to address threats to global human security.

Fourth, the concept of human security emphasises a holistic approach and drives our attention to the root causes by emphasising that health security cannot be achieved without strengthening health systems and without addressing the social and economic exclusion of certain population groups. Recent studies have pointed out the role of public health measures in East Asia-that include not only the improvement in public health systems of emergency preparedness but also expansion in universal health coverage, growth in per capita spending on health per capita and improvement in healthcare delivery-as the major factor in the relative success of these countries in addressing the coronavirus pandemic. $^{37} 38$ 
Fifth, the concept of human security is based on universalism and unlike the traditional development paradigms that locate the problems of human vulnerabilities in the developing world, the concept of human security recognises various forms of human vulnerabilities in the developed world. The COVID-19 pandemic has exposed these vulnerabilities in many developed countries.

Summing up, the key characteristics of the human security approach described above such as (a) universalism that defies 'we' versus 'they' dichotomy by locating the problems of human insecurity in both the developing and the developed world; (b) interconnectedness that avoids 'in-silo' securitisation by emphasising an interconnected understanding of security; (c) indivisibility of threats that links humanity and the collective threats that it faces; (d) emphasis on collective action and interstate cooperation to address problem of global human security; and (e) the attention to downside risks emphasising prevention rather than the cure, makes this concept more relevant and effective to conceptualise public health security.

\section{CONCLUSION}

The global crisis unleashed by the ongoing COVID-19 pandemic has exposed flaws in our existing state-centric notion of health security. The crisis calls for reconceptualising health security using a broader and a more holistic notion of security-an imperative that has also been recently emphasised by scholars as the first step toward formulating a global treaty on pandemic preparedness and response. ${ }^{24}$ In this article, we revisited the notion of human security and examined some distinctive features of this paradigm that hold deeper implications and relevance for conceptualising health security in an era of increased global connectivity and pandemics.

Given the political and economic reality of the world that we live in, global narratives and actions are often the outcome of power politics. Current times offer both challenges and opportunities. The surge in global populism and nationalism poses challenges in promoting global cooperation, solidarity and multilateralism. However, major crises in the past have provided turning points in shifting global discourses and restructuring public policy. The current crisis also offers opportunities in a number of ways. First, the COVID-19 pandemic and its economic and social consequences may offer the resonance that the concept may need for its political acceptance. Political realism today would demand greater investment in health security to ensure both economic and state security. The pandemic illustrates that the domestic benefits of investing in health security and enhancing transparency in sharing information about the outbreak far outweigh the domestic costs of doing so.

Second, the unipolar world is weakening up and the global balance of economic and political power is shifting, providing space to some middle powers to exercise greater influence. These countries can use their 'soft power' to promote a broader public health security agenda. Many initiatives in the past to reform global institutions to advance the cause of human security were taken by the middle powers. ${ }^{39}$ The strengthening of existing global institutions such as the WHO and the establishment of new institutions at the global level are needed to promote global health security.

Third, the role of civil society in the transformation of global consciousness has grown and many public health problems of global significance such as pandemics and climate change posing major threats to human well-being can clearly be framed as human security issues. Finally, and most importantly, the world is ready for a transition to a new vision that leads to a more secure and healthy world.

Twitter Sadia Mariam Malik @SadiaMariamMal1

Contributors SMM conceived the study. SMM, $A B$ and BJ reviewed literature. $A B$ and BJ provided research assistance and drafted the background papers. SMM drafted the original manuscript. All authors contributed content, recommended referenced work and approved the final manuscript.

Funding This work was funded by a seed grant from Dahdaleh Institute of Global Health Research, Canada.

Competing interests None declared.

Patient consent for publication Not required.

Provenance and peer review Not commissioned; externally peer reviewed.

Data availability statement All data relevant to the study are included in the article.

Open access This is an open access article distributed in accordance with the Creative Commons Attribution Non Commercial (CC BY-NC 4.0) license, which permits others to distribute, remix, adapt, build upon this work non-commercially, and license their derivative works on different terms, provided the original work is properly cited, appropriate credit is given, any changes made indicated, and the use is non-commercial. See: http://creativecommons.org/licenses/by-nc/4.0/.

\section{ORCID iD}

Sadia Mariam Malik http://orcid.org/0000-0002-9286-2032

\section{REFERENCES}

1 Aldis W. Health security as a public health concept: a critical analysis. Health Policy Plan 2018;23:369-75.

2 Rushton S. Global health security: security for whom? security from what? Polit Stud 2011;59:779-96.

3 Commission on Human Security. Human security now. New York, 2003.

4 Lo Yuk-ping C, Thomas N, Yuk-Ping L. How is health a security issue? politics, responses and issues. Health Policy Plan 2010;25:447-53.

5 Ingram A. The new geopolitics of disease: between global health and global security. Geopolitics 2005;10:522-45.

6 Labonté R, Gagnon ML. Framing health and foreign policy: lessons for global health diplomacy. Global Health 2010;6:14.

7 Fidler P. Public health and national security in the global age: infectious diseases, bioterrorism, and realpolitik. articles by Maurer faculty, 2003. Available: https://www.repository.law.indiana.edu/ facpub/416

8 Buzan B, Ole W, Wilde J. Security: A new framework for analysis. London: Lynne Rienner Publishers, 1998.

9 Cox RW. Social forces, states and world orders: beyond international relations theory. Millennium 1981;10:126-55.

10 Cox W. Production, power, and world order. New York: Columbia University Press, 1987.

11 Browning CS, McDonald M. The future of critical security studies: ethics and the politics of security. Eur J Int Relat 2013;19:235-55

12 Singer PW. Aids and international security. Survival 2002;44:145-58.

13 Peterson S. Epidemic disease and national security. Security Studies 2002;12:43-81. 
14 AlTakarli NS. China's Response to the COVID-19 Outbreak: A Model for Epidemic Preparedness and Management. Dubai Medical Journal 2020;3:44-9.

15 China Daily. Epidemiologists explain why China can WIN war on COVID-19. 2020-7-17. Available: https://covid-19.chinadaily.com.cn/ a/202007/17/WS5f10fec2a31083481725a19a.html

16 Ning Y, Ren R, Nkengurutse G. China's model to combat the COVID-19 epidemic: a public health emergency governance approach. Glob Health Res Policy 2020;5:34.

17 PRC. (People's Republic of China). Priorities key to victory over big challenges. National Health Commission of the People's Republic of China, 2020. http://en.nhc.gov.cn/2020-05/18/c 80249.htm

18 Government of Japan. Japan's security and defence policy. Ministry of Defence, 2020. Available: https://www.mod.go.jp/e/publ/w_paper/ wp2020/pdf/index.html

19 Panda A. Indian army prepares to assist in virus response measures. The diplomat, 2020. Available: https://thediplomat.com/2020/03/ indian-army-prepares-to-assist-in-virus-response-measures/

20 Ramananda S. Corona Warriors: How Indian army is contributing to battle against COVID-19. Outlook, 2020.

21 Davies SE. Securitizing infectious disease. Int Aff 2008;84:295-313.

22 McINNES C, LEE K, Kelley L. Health, security and foreign policy. Rev Int Stud 2006;32:5-23.

23 Nunes J. Questioning health security: insecurity and domination in world politics. Rev Int Stud 2014;40:939-60.

24 Fukuda-Parr S, Buss P, Ely Yamin A. Pandemic Treaty needs to start with rethinking the paradigm of global health security. BMJ Glob Health 2021;6:e006392.

25 Chen L, Narasimhan V, Vasant N. Human security and global health. Journal of Human Development 2003;4:181-90.

26 Acharya A. Human security: East versus West. International Journal 2001. 2001; Summer.

27 UNDP (United Nations Development Programme). Human Development Report. New York: Oxford University Press, 1994.

28 Fukuda-Parr S. New threats to human security in the era of globalization. Journal of Human Development 2010;4:2003. Volume.

29 Sen A. Development as freedom. UK: Anchor Books, 2000.

30 Haq M. The new imperatives of human security. World Affairs: The Journal of International Issues 1995;4:68-73.

31 Turner M, Neil C, Michael P. Institutionalised and co-opted: Why human security has lost its way. In: Chandler D, Hynek N, eds. Critical perspectives on human security: rethinking emancipation and power in international relations. New York: Routledge, 2011: 83-96.

32 Tadjbaksh S, Anuradha C. Human security: concept and implications. New York: Routledge, 2007.

33 Greaves W. For whom, for what? Canada's Arctic policy and the narrowing of human security. International Journal 2012:2011-2.
34 MacArthur J. A responsibility to rethink? challenging paradigms in human security. International Journal 2008;2008.

35 Paris R. Human security: paradigm shift or hot air? Int Secur 2001;26:87-102

36 Alkire S. A conceptual framework for human Security." Working Paper 2. Centre for Research on Inequality, Human Security, and Ethnicity, University of Oxford, 2003.

37 Khor K, David H. An Asian pandemic success story: what SARS taught governments about fighting infectious disease. Foreign Affairs 2020;2020.

38 Lal A, Erondu NA, Heymann DL, et al. Fragmented health systems in COVID-19: rectifying the misalignment between global health security and universal health coverage. Lancet 2021;397:61-7.

39 Behringer M. The human security agenda: how middle power leadership defied us hegemony. Continuum International, 2012.

40 White House. National security strategy of the United States of America, 2017.

41 Government of India. Annual report, 2018-2019. Ministry of Defense.

42 People's Republic of China. China's national defence in the new era. The State Council Information Office of the People's Republic of China, 2019.

43 Directorate-General for External Policies Policy Department. Russia's national security strategy and military doctrine and their implications for the EU. European Parliament.

44 Department of Defense,. Republic of South Africa. Department of defence annual report. Republic of South Africa, 2018.

45 Republic of Indonesia. Defence white paper. Defence Ministry of the Republic of Indonesia, 2015.

46 Public Safety Canada. Securing an open society: Canada's national security policy.

47 Health Canada. Learning from SARS: renewal of public health in Canada. A report of the National Advisory Committee on SARS and public health, 2003.

48 Department of the Prime Minister and Cabinet, Australia. Strong and secure: a strategy for Australia's national security, 2013.

49 HM Government. National security capability review. Cabinet Office, U.K, 2018.

50 Mitchell I. The integrated review - Re-defining the UK's role in the world. Centre for Global Development, 2020.

51 Government of France. French white paper: defense and national security, 2013.

52 Republic of Italy. White paper for international security and defense. The ministry of defense, 2015

53 Council of the European Union. European security strategy: a secure Europe in a better world. European Communities, 2009. 